\title{
CAN DIGITAL RESEARCH BE AN ALTERNATIVE METHOD DURING THE COVID-19 PANDEMIC IN INDONESIA?
}

\author{
Bahtiar Rifai ${ }^{1}$, Meilinda Sari Yayusman², Vera Bararah Barid ${ }^{3}$ \\ ${ }^{I}$ Research Center for Economics, Indonesian Institute of Sciences (LIPI) \\ ${ }^{2}$ Research Center for Area Studies, Indonesian Institute of Sciences (LIPI) \\ ${ }^{3}$ Research Center for Society and Culture, Indonesian Institute of Sciences (LIPI) \\ Corresponding Author Email: bahtiar2ooo@gmail.com
}

\begin{abstract}
Unprecedented COVID-I9 global pandemic entails uncertain conditions, which lead people to seek alternative solutions to make activities running accordingly. Limited movements due to travel restriction and health protection confine people's activities, including the research process. Postponing research activities is arguably not the best solution for scholars, mainly while conducting data collection. In social and humanities research, researchers mostly undertake data collection through field studies and face-to-face communications prior to the pandemic. Social distancing procedures, however, encourage people to avoid close contacts and cancel visit plans. Thus, researchers are necessary to find an alternative method during uncertainty situation. Digital research method (DRM) seems to be a plausible way to keep research ongoing, although the implementation of that method in the developing countries' research activities, compared to the developed countries, remains lagging behind. This research aims to position DRM amidst the pandemic situation and show possibilities in using this method as an alternative in the developing countries by taking Indonesia as a case study. Results show that to make DRM works in Indonesia, some requirements need to be fulfilled to meet academic standards, and whether relevant or not the research topic applies to be processed utilizing digital method are also essential to be considered.
\end{abstract}

Keywords: COVID-I9, Digital research method (DRM), Indonesia, social and humanities research

\section{Abstrak}

Pandemi global COVID-I9 yang belum pernah terjadi sebelumnya berdampak pada ketidakpastian dalam berbagai hal dan menyebabkan banyak orang berusaha mencari solusi alternatif agar aktivitas mereka tetap berjalan. Pembatasan gerak yang dikarenakan oleh larangan berpergian dan usaha penjagaan kesehatan membatasi aktivitas manusia termasuk dalam proses penelitian. Menunda aktivitas penelitian bukan menjadi solusi terbaik untuk para akademisi terlebih saat melakukan pengumpulan data. Dalam penelitian ilmu sosial, para peneliti kebanyakan melakukan pengumpulan data dengan berkunjung ke lapangan dan komunikasi tatap muka. Akan tetapi, peraturan untuk menjaga jarak menginstruksi banyak orang untuk menghindari kontak jarak dekat dan membatalkan rencana kunjungannya. Untuk itu, para peneliti perlu untuk mencari metode alternatif. Metode riset digital dianggap memungkinkan sebagai cara untuk membuat penelitian tetap berjalan walaupun implementasinya di negara-negara berkembang masih tertinggal dibandingkan negara-negara maju. Penelitian ini bertujuan untuk memposisikan metode penelitian digital di tengah situasi pandemi dan menunjukkan beberapa kemungkinan dalam menggunakan metode ini sebagai alternatif dalam penelitian di negara berkembang dengan mengambil studi kasus Indonesia. Hasil penelitian memperlihatkan bahwa untuk membuat metode digital berjalan di Indonesia, beberapa persyaratan perlu dipenuhi agar dapat sesuai dengan standar akademik dan apakah topik riset relevan atau tidak dengan menggunakan metode digital juga penting untuk dipertimbangkan.

Kata kunci: COVID-I9, Metode penelitian digital, Indonesia, penelitian sosial dan humaniora 


\section{INTRODUCTION}

The COVID-I9 global pandemic affects human mobilities in the shape of limited movements and distanced contact, encouraging them to find an alternative way to make their activities run accordingly. Travel restrictions are also stipulated to protect people from infectious viruses. However, this unprecedented situation remains uncertain whether or not it will last longer than expected. Limited movements and social distancing procedures also affect the research activities, particularly in social and humanities studies. Research which is normally conducted through field study and face-to-face communications, is required to adjust to this uncertain situation.

Postponing research activities are also impossible. Thus, this pandemic condition encourages researchers to find an alternative method to ensure that research keeps ongoing. Digital research method (DRM) becomes an option to make social and humanities research workable to be undertaken. Snee, et.al. (2016) defines digital methods as the use of online and digital technology to collect and analyze research data. A wide range of digital methods implementation has also been utilized to undertake various research, such as social media analysis, social networks analysis, content analysis, web-based surveys, educational research, and in-depth online interviews or focus group discussions with the support of innovative digital research software and toolkit.

In Indonesia, researchers embark on thinking of DRM for their research activities. Taking an example of what has been conducted in the Indonesian Institute of Sciences (LIPI) through a set of workshop activities, DRM is considered. Nonetheless, in developed countries, hereafter the developing countries, including Indonesia, the use of DRM in research is still left unexplored. Unlike the developing countries, the use of DRM in the developed countries, is well established, and researchers in the developed countries have found many innovative ways to best use digital methods in their research activities. Besides, the global pandemic situation can be seen as an opportunity to implement DRM in research and develop it in the developing countries, particularly
Indonesia.

The superiority of the developed countries in economy, quality of human resources, research facilities and education brings sovereignty in knowledge and sciences. The concept of DRM has been well developed since early 20I0, started by introducing the concept of DRM, establishing suitable digital software, and publishing papers and books (Hewson, 20I6; Snee et al., 2016). On the other side of the world, the developing countries have limitations in providing a sufficient research environment (Horton, 2000; Koehn, 20I4). As a result, knowledge generation has been delayed in the developing countries compared to developed countries, including DRM. Implementation of DRM in research activities in the developing countries just started due to pandemic Covid-I9. Since most DRM theories produced by the developed countries, this paper contributes to providing DRM concept from developing countries' perspective, particularly from Indonesia, which have not been so popular in literature. Therefore, this article may bridge the knowledge of DRM to implement in the other countries in developing countries.

Despite its optimistic potential for supporting data collection and analysis, many aspects are still necessary to be concerned to ensure that the emerged DRM in the developing countries meet academic standards. To be more precise, this research aims to position DRM amidst the pandemic situation and show possibilities to use it as an alternative method in social and humanities research. In doing so, the ensuing sub-chapters examine how DRM could be an alternative for scholars in the developing countries but remains fulfilling academic standards by explaining the essence of DRM as an alternative in the middle of pandemic posing its strengths and weaknesses based on experiences taken during workshops.

\section{RESEARCH METHOD}

This article employed primary data and secondary data as the source of analysis. Primary data were collected through observation to 84 participants of DRM workshop over two 
months. The participants consist of early career researchers and young researchers from the Indonesian Institute of Sciences (LIPI) in the Deputy of Social and Humanities. This method aims to identify the process, opportunity (strengths), obstacles (limitations), and challenges encountered by participants in learning and adopting DRM during the workshop and post-workshop (DRM implementation in research design) (see the following table). As the observers, authors were involved in all workshop meetings (I6 times) which every meeting took at least three and up to four hours. The workshop was undertaken within three months (August to October 2020). Since the COVID-I9 pandemic was getting imperative, all workshop meetings were delivered online using Zoom Meetings (ZM) that require a sufficient internet connection. There were three sections of observation, pre-workshop, during the workshop, and post-workshop to identify the element of DRM and its implementation by social and humanities research in LIPI.

Secondary data were collected through literature study as the primary data resources such as journals, books, and institutions' documents. Secondary data over publications help develop a research framework, revisit existing theories, and extend current studies on a specific topic. Investigating the appropriate works of literature are popularly undertaken in qualitative research (Wildemuth, 20I6). The sources of paper publications are majorly from international journals but not to limit national journals. In terms of papers' search strategy, this study focuses on papers with more frequently cited sources from journals of social research methodology, communication research practice, social and behavioral sciences, and research management. Also, we set up keywords to search some papers relevant to this study's objective, for instance: digital research, DRM, social sciences and humanities, pandemic, COVID-I9. While tracing documents and related official data were employed to strengthen the analysis.

To identify how DRM can be employed as an alternative method to obtain and process data during the pandemic, we use a qualitative approach. This approach helps to record, identify, investigate, and reveal the profound meaning of participants' responses and experiences during the workshop (Ezzy, 20I3). Therefore, these may exhibit some DRM opportunities that can be academically conducted as an alternative method during the pandemic.

The qualitative approach allows the flexibility of data collection in textual form from observation and interaction during the digital research's workshop, such as workshop participants' observation and focus group discussions.

Table I. Primary Data Collection through DRM Workshop participants observation

\begin{tabular}{|c|c|c|c|c|}
\hline \multirow{2}{*}{ Section } & \multicolumn{3}{|c|}{ Primary data collection approach } & \multirow{2}{*}{ Aspect to identify } \\
\hline & Participant's observation & FGD with researchers & Survey online & \\
\hline \multirow[t]{4}{*}{ Pre-Workshop } & & Discuss desired & & Identification required \\
\hline & & software, soft skills for & & skills, types of training, \\
\hline & & DRM, task, and meeting & & understand-ing concept \\
\hline & & delivery & & \\
\hline \multirow[t]{3}{*}{ Workshop } & Reporting difficulties & & & $\begin{array}{l}\text { Process, strength constraints, } \\
\text { opportunity }\end{array}$ \\
\hline & $\begin{array}{l}\text { Questions during online } \\
\text { meeting }\end{array}$ & & & $\begin{array}{l}\text { Process, constraints, } \\
\text { opportunity }\end{array}$ \\
\hline & Project presentation & & $\begin{array}{l}\text { Feedback of workshop } \\
\text { implementation }\end{array}$ & $\begin{array}{l}\text { Understand-ing concept, } \\
\text { Challenges to employ DRM }\end{array}$ \\
\hline Post Workshop & $\begin{array}{l}\text { Implementation in } \\
\text { design research }\end{array}$ & & & $\begin{array}{l}\text { Comment from independent } \\
\text { reviewers about participants' } \\
\text { understand-ing for concept } \\
\text { and software of DRM }\end{array}$ \\
\hline
\end{tabular}

Source: Author 


\section{LITERATURE REVIEW}

The recent development of technology has led to the emergence of research methods in any academic fields. Innovative tools and software to support digital research methods have also widely been developed, and the implementation has also been widespread across the world. Particularly in the developed countries, DRM usage is not uncommon to assist research data collection and analysis.

Given that situation, the use of digital methods in the developing countries, is not as advanced as what has been implemented in the developed countries. Unlike in the developed countries, the implementation of DRM in the developing countries is still lagging. If any, researchers in the developing countries start to eagerly consider harnessing DRM when the COVID-I9 global pandemic hits the world and see this method as an alternative to run the research. This part demonstrates a literature review regarding the development of DRM, and the extent to which this method has been thrived to underpin manifold research disciplines, especially in social and humanities studies.

It is prominent to see deeper of a great transformation in research and outline a comparison of the implementation of the digital method in two separated yet inextricable actor groups that play a pivotal role in the global system. Sandvig \& Hargittai (2015) have also pointed out the urge to learn digital research transformation; he stated that digital media research processes deserve attention because they produce new methods, new opportunities, and new challenges for understanding human behavior and society. This context represents digital methods as part of research innovation and a new kind of science that deserves to be explored.

It goes without saying that Internet development's social significance can be considered as a starting point where the advent of DRM was introduced. In the mid-I990s, the Internet became a mainstream phenomenon and was providing a fascinating resource for doing social science research (Snee, et. al., 20I6). Other scholars such as Lazer, et. al. (2009) also had a similar belief that the Internet is an instrument that could enable a similar revolution of revelation for the social sciences. Since the emergence of the Internet, social interactions and data access are widely open, making people easier to gather information and conduct observation to broader society. Sandvig \& Hargittai (2015) also added that the Internet might offer more efficient, cheaper, or otherwise superior iterations of existing research methods. Despite positive responses to Internet development, some scholars also express their critiques of the overwhelming use of it. Beer (2013) stated that this contemporary Internet had become a complex and multifaceted arena that both reflects and reshapes everyday life. Therefore, the effective use of the Internet in research should be studied thoroughly, but, still, the Internet can be seen as a mark of transformation for the development of digital methods in social and humanities research.

Successive responses on the Internet development have resulted in the emergence of digital methods and how it has been utilized in a wide array of research practices ranging from data collection to data analysis. Originally said as Internet research, this was founded largely on the recognition that the Internet could act as a novel site for social formations (Hine, 2008), from which the support of online features could undertake any practices that were usually done face-to-face. Also, the emergence of digital methods leads to some innovative computation-based analysis that could interpret data and assist in the analysis process. In the developed countries, digital methods for the purpose of data collection or data analysis have been done in certain research activities as follows.

Data collections such as through interviews and group discussions have become routine, both in asynchronous mode and in real time (Kazmer \& Xie, 2008; James \& Busher, 2009; Salmons, 20II). Hine (2008) also highlighted that social researchers have widely accepted online interviews. Furthermore, interviewing online has become normal in research conducted by researchers in the developed countries, considering time-efficiency and travel removal costs. Some scholars also added 
that interviewing online can offer a safe space for participants to address sensitive issues (Illingworth, 200I; Orgad, 2005; McCoyd \& Kerson, 2006), and also provide a space for those who are hard to fit face-to-face interviews (Madge \& O'Connor, 2002; Nicholas, et. al., 20I0). However, other scholars such as Shap$\mathrm{ka}$, et. al. (2016) criticized that online interviews produced fewer words, took longer, and required more rapport building. It is sometimes hard to derive in-depth understanding, including capturing the genuine emotions.

Despite apparent debates, digital methods for data collection continuously invent certain means to gather data. Web crawling and data tracing have best used the Internet and mustered what called 'big data' to get the information necessary for research analysis and findings. Web crawling in social science research undertakes copy data activities from websites and organise the data into particular formats (Shumate \& Weber, 2015). To implement this activity, many available programs can help to do crawling data needed. Of research activities conducted by Turner, et. al. (2005), it was also stated that web crawling could be used to map information flow and social interaction on the Web. This part will be a benefit to what we called next as social network analysis. Like web crawling, data tracing also becomes part of innovative ways in digital methods for data collection. Trace data can be obtained from a varied of sources including Scraping (Wesler, et. al., 2008), Application Programming Interface (API) (Morstatter, et. al., 20I3), programs designed to collect trace data (Hansen, et. al., 20II), custom applications and computer scripts (Fiore, et. al., 2002; Hampton, 2007), online text corpuses from email lists, text messages, discussion forums, and archives (Evan \& Aceves, 20I6; Gad, et. al., 2015), and partnership with companies such as Facebook and Microsoft (Burke, et. al, 20Io; Ellison, et. al., 20I4). A critique for tracing data in data collection has been added by Schober, et. al. (20I6); he stated that trace data might not represent the broader population. From this criticism, it is understood that sometimes data gathered online, especially from social media, may only represent certain personal opinions and cannot capture a wider society and certain emotions.

In a quantitative approach, a web-based survey or questionnaire is often conducted to collect data. Researchers collect the data by designing some questions leading to novel findings obtained when wider participation and perspectives are gathered. Some software such as SurveyMonkey, Typeform, Qualtrics, Lime Survey and many others (Haije, 202I) provide templates to ease researchers designing survey and questionnaire and sums up results in various ways that could assist them to analyze data after the result came out. However, during the implementation, informant accuracy to the data sometimes becomes a challenge. The way the informants or wider society answers questions are sometimes debatable to guarantee that the result is accurate. Whether or not the informants know the topic and answers questions seriously may affect the survey results.

Moving to the analysis process, researchers in the developed countries have arguably been supported with a skill set to conduct analysis harnessing digital software and tools. Some analyses utilizing digital software and tools are then invented to complete academic scholarship and show the advancement of digital methods. Social media analysis, social network analysis, content analysis, and video analysis are some instances to show the progress in the extent to which the developed countries have successfully been brought analytical framework using digital methods. Social network analysis (SNA), as the popular one used in research, has been widely used by social science experts to study social structures and networks since I920s (Zhang, 20I0). Freeman (2004) also added that in social science, the structural approach that is based on the study of interaction among social actors is called SNA. Preceding works of Wetherell, et. al. (1994) defines broadly social network analysis as,

'(I) to conceptualise social structure as a network with ties connecting members and channelling resources, (2) to focus on the characteristics of ties rather than on the characteristics of the individual members, and (3) to view communities as 'personal communities', that is, as networks of individual relations that people fos- 
ter, maintain, and use in the course of their daily lives.' (p. 645).

This definition depicts specific objectives why SNA works for research in some academic fields. In addition to that, the actors in social networks can be persons, organizations, or groups, and may be used on different levels ranging from individuals, web pages, families, small groups, to large organization parties, and even nations (Zhang, 20Io). The overall aim is to see connections and interactions among actors in a group rather than perceive human behavior or any interactions individually or separately. Although some scholars, in fact, have found SNA as part of academic works to analyze data since a long time ago, the Internet development leads this analysis method to be more advanced, harnessing digital technology to support data gathering to which sometimes we called it as 'big data. With the help of technology and software innovation, a large amount of data can be stored in a database that could be accessed using a computer programming language such as Structured Query Language (SQL) (Welles, 20I5). Data collection could be gathered from server-side records software, which provides complete records user interaction and action originated from Twitter, Facebook, or other social medias. It is therefore the social media plays a central role nowadays to be a supporting feature in data collection from which social media analysis for scientific research are also developed.

Social media users are also increasing as basic needs to interact and gain updated information. The contemporary social media can be understood in terms of a "platform paradigm' (Burgess, 2014) in which all kinds of communications is being mediated via platforms like Facebook and Twitter, and those platforms show communication that can also be monetized and analyzed (Bruns \& Burgess, 20I6). Using API through web-crawling and data tracing, data can be collected and analyses on human interactions and behaviors can be done. Social media analysis, in short, aims to explore how occurring social interaction data can be mined and to understand the dynamics of self-organizing system, information diffusion, and social influence (Burgess, 2016), especially for research purposes. If this ana- lytic goes deeper, SNA arguably plays a role to continue this analysis process.

Furthermore, content analysis, text analysis, and video analysis are also some emerging research analysis means in social science in the developed countries. It shows a variety of analysis that can be undertaken utilizing technology and for some parts should also be supported by the use of innovative software. For instance, content analysis and text analysis in which data gathered from interviews or group discussions can be extracted via Nvivo software, a coding-based quantitative and qualitative software that can scrutinize a series of text documents resulting from FGDs or interview transcripts. The result could show tendencies on what topics are in favor amidst discussions and analyze the process of discussions. Such software could also help draw project or conceptual map, illustrating how people think based on collected interview or group discussion transcripts. However, content analysis could also help analyze the data from what appears on the Internet. Many contents in various media platforms, such as social media, digital news, and official websites, can be examined, showing greater activities using technology and how people actively interact with each other to be the object of analysis. According to Krippendorff (2004), content analysis has always straddled the line between quantitative and qualitative methods, meaning that it sometimes uses for both purposes in digital research. Other scholars, like Hesse-Biber \& Leavy (2008), define content analysis as a familiar approach for such large-scale endeavor, translating the Internet situation in which the focus was on the content of individual messages. Any individual messages spread on the Internet can be further examined, and researchers have also been analyzing the content of other media to explore technology use, such as video recordings or documentaries.

Still, in data analysis activities, the emerging of technology nowadays can produce innovative and creative products such as videos that can be the research part. From that, analysis on the content of certain videos can be translated into valuable findings for research. In social science research, video analysis often refers to digital ethnographic activities. Kno- 
blauch \& Schnettler (2012) argues that video analysis - the sequential analysis of interactional video data - requires methodological rigor along with a deep foundation in ethnographic fieldwork. It means that video analysis needs support evidence from fieldwork experiences to feel the actual condition to interpret the video. During the analysis, similar to other analysis processes, the use of Computer Assisted Qualitative Data Analysis Software (CAQDAS) has become standard practice in qualitative analysis using a video as one of the resources. CAQDAS functions to aid researchers and present video transcripts (Roock, et. al., 2016). Here again, the use of technology is used to develop such useful software like CAQDAS and contribute to developing digital methods by conducting video analysis for underpinning research findings and results.

The aforementioned activities exemplify the advent of digital methods in social science research in data collection and analysis. In so doing, DRM development in social science research can be concluded as follows,

Table 2. Digital research method purposes and implementations

\begin{tabular}{|c|c|c|c|}
\hline Methods & Purposes & $\begin{array}{l}\text { Implemen- } \\
\text { tation }\end{array}$ & $\begin{array}{l}\text { Software/ } \\
\text { tools used }\end{array}$ \\
\hline $\begin{array}{l}\text { Online } \\
\text { interviews }\end{array}$ & $\begin{array}{l}\text { To collect } \\
\text { in-depth } \\
\text { information } \\
\text { usually from } \\
\text { individual } \\
\text { informant. } \\
\text { Sometimes } \\
\text { informants } \\
\text { need privacy, } \\
\text { so they } \\
\text { prefer to be } \\
\text { interviewed } \\
\text { online. }\end{array}$ & $\begin{array}{l}\text { Replacing } \\
\text { face-to-face } \\
\text { interviews } \\
\text { by online } \\
\text { utilizing } \\
\text { supported } \\
\text { digital } \\
\text { platform } \\
\text { software. }\end{array}$ & $\begin{array}{l}\text { Zoom, } \\
\text { Skype, } \\
\text { Google Meet, } \\
\text { Whatsapp } \\
\text { Calls, etc. }\end{array}$ \\
\hline $\begin{array}{l}\text { Online } \\
\text { focus group } \\
\text { discussions }\end{array}$ & $\begin{array}{l}\text { To collect } \\
\text { in-depth } \\
\text { information } \\
\text { from some } \\
\text { informants } \\
\text { relevant to } \\
\text { the topic. }\end{array}$ & $\begin{array}{l}\text { Replacing } \\
\text { face-to- } \\
\text { face group } \\
\text { discussions } \\
\text { by online } \\
\text { utilizing } \\
\text { digital } \\
\text { platform } \\
\text { software. }\end{array}$ & $\begin{array}{l}\text { Zoom, } \\
\text { Skype, } \\
\text { Google Meet, } \\
\text { Microsoft } \\
\text { Teams, etc. }\end{array}$ \\
\hline
\end{tabular}

\begin{tabular}{|c|c|c|c|}
\hline $\begin{array}{l}\text { Web- } \\
\text { crawling and } \\
\text { data tracing }\end{array}$ & $\begin{array}{l}\text { To undertake } \\
\text { copy data } \\
\text { activities } \\
\text { from } \\
\text { websites and } \\
\text { organize the } \\
\text { data into } \\
\text { particular } \\
\text { formats } \\
\text { and to map } \\
\text { information } \\
\text { flow and } \\
\text { social } \\
\text { interaction } \\
\text { on the Web. }\end{array}$ & $\begin{array}{l}\text { Tracing data } \\
\text { from various } \\
\text { sources and } \\
\text { methods } \\
\text { such as } \\
\text { utilizing } \\
\text { Scraping } \\
\text { software, } \\
\text { API, custom } \\
\text { applications } \\
\text { and } \\
\text { computer } \\
\text { scripts, } \\
\text { online text } \\
\text { corpuses, } \\
\text { partnership } \\
\text { with } \\
\text { companies } \\
\text { like } \\
\text { Facebook, } \\
\text { Twitter, and/ } \\
\text { or Microsoft. }\end{array}$ & $\begin{array}{l}\text { Scraper, } \\
\text { DeepVisual, } \\
\text { Webhose.io, } \\
\text { ParseHub, } \\
\text { Octoparse, } \\
\text { Getleft, etc. }\end{array}$ \\
\hline $\begin{array}{l}\text { Web- } \\
\text { survey and } \\
\text { question- } \\
\text { naire }\end{array}$ & $\begin{array}{l}\text { To undertake } \\
\text { copy data } \\
\text { activities } \\
\text { from } \\
\text { websites and } \\
\text { organize the } \\
\text { data into } \\
\text { particular } \\
\text { formats } \\
\text { and to map } \\
\text { information } \\
\text { flow and } \\
\text { social } \\
\text { interaction } \\
\text { on the Web. }\end{array}$ & $\begin{array}{l}\text { Designing } \\
\text { a series of } \\
\text { questions } \\
\text { that } \\
\text { should be } \\
\text { answers by } \\
\text { respondents. } \\
\text { The } \\
\text { questions } \\
\text { could be } \\
\text { open-ended, } \\
\text { close-ended, } \\
\text { or multiple } \\
\text { choices. }\end{array}$ & $\begin{array}{l}\text { Scraper, } \\
\text { DeepVisual, } \\
\text { Webhose.io, } \\
\text { ParseHub, } \\
\text { Octoparse, } \\
\text { Getleft, etc. }\end{array}$ \\
\hline $\begin{array}{l}\text { Social } \\
\text { network } \\
\text { analysis }\end{array}$ & $\begin{array}{l}\text { To see the } \\
\text { connections } \\
\text { and } \\
\text { interactions } \\
\text { among } \\
\text { actors in a } \\
\text { group rather } \\
\text { than perceive } \\
\text { a human } \\
\text { behavior } \\
\text { or any } \\
\text { interactions } \\
\text { individually. }\end{array}$ & $\begin{array}{l}\text { Collecting } \\
\text { data from } \\
\text { server-side } \\
\text { records } \\
\text { software, } \\
\text { which } \\
\text { provide } \\
\text { complete } \\
\text { records user } \\
\text { interaction } \\
\text { and action } \\
\text { originated } \\
\text { from social } \\
\text { medias, and } \\
\text { analyzing } \\
\text { it using } \\
\text { software } \\
\text { to see the } \\
\text { nodes that } \\
\text { depict actors' } \\
\text { interactions }\end{array}$ & $\begin{array}{l}\text { Gephi, } \\
\text { Netlytics, } \\
\text { Centrifuge, } \\
\text { R, NodeXL, } \\
\text { etc. }\end{array}$ \\
\hline $\begin{array}{l}\text { Social media } \\
\text { analysis }\end{array}$ & $\begin{array}{l}\text { To explore } \\
\text { how } \\
\text { occurring } \\
\text { social } \\
\text { interaction } \\
\text { data can be } \\
\text { mined and to } \\
\text { understand } \\
\text { the dynamics } \\
\text { of self- } \\
\text { organizing } \\
\text { system, } \\
\text { information } \\
\text { diffusion, } \\
\text { and social } \\
\text { influence. } \\
\text { SNA can } \\
\text { potentially } \\
\text { continue } \\
\text { this analysis } \\
\text { process. }\end{array}$ & $\begin{array}{l}\text { Collecting } \\
\text { and } \\
\text { analyzing } \\
\text { data on } \\
\text { human } \\
\text { interactions } \\
\text { and } \\
\text { behaviors } \\
\text { from social } \\
\text { medias by } \\
\text { harnessing } \\
\text { software and } \\
\text { pogramming }\end{array}$ & $\begin{array}{l}\text { Hotsuite, } \\
\text { Snaplytics, } \\
\text { HubSpot, } \\
\text { Sprout } \\
\text { Social, } \\
\text { Google } \\
\text { Analytics, } \\
\text { etc. }\end{array}$ \\
\hline
\end{tabular}




\begin{tabular}{|c|c|c|c|}
\hline $\begin{array}{l}\text { Content and } \\
\text { text analysis }\end{array}$ & $\begin{array}{l}\text { To analyze } \\
\text { contents } \\
\text { appeared on } \\
\text { the Internet } \\
\text { or social } \\
\text { media, and } \\
\text { to analyze } \\
\text { text derived } \\
\text { from } \\
\text { in-depth } \\
\text { interviews, } \\
\text { group } \\
\text { discussions, } \\
\text { or any } \\
\text { interactions. }\end{array}$ & $\begin{array}{l}\text { Processing } \\
\text { data } \\
\text { gathered } \\
\text { from the } \\
\text { Internet } \\
\text { or from } \\
\text { discussions } \\
\text { and } \\
\text { interview, } \\
\text { interpreting } \\
\text { it utilizing } \\
\text { software } \\
\text { (e.g.: in } \\
\text { Nvivo, } \\
\text { the data is } \\
\text { processed } \\
\text { by coding } \\
\text { method) } \\
\text { to obtain } \\
\text { findings. }\end{array}$ & $\begin{array}{l}\text { Nvivo, } \\
\text { Netlytics, } \\
\text { MAXQDA, } \\
\text { Atlas.ti., } \\
\text { RQDA, etc. }\end{array}$ \\
\hline $\begin{array}{l}\text { Video } \\
\text { analysis }\end{array}$ & $\begin{array}{l}\text { To analyze } \\
\text { certain } \\
\text { conditions } \\
\text { from } \\
\text { interactional } \\
\text { video data. }\end{array}$ & $\begin{array}{l}\text { Gathering } \\
\text { videos } \\
\text { related to } \\
\text { the topics } \\
\text { or capturing } \\
\text { videos while } \\
\text { conducting } \\
\text { fieldworks, } \\
\text { extracting } \\
\text { video } \\
\text { transcripts } \\
\text { utilizing } \\
\text { supporting } \\
\text { software, and } \\
\text { interpreting } \\
\text { the videos to } \\
\text { understand } \\
\text { the real } \\
\text { condition on } \\
\text { the ground. }\end{array}$ & $\begin{array}{l}\text { CAQDAS, } \\
\text { Google Video } \\
\text { Intelligence, } \\
\text { Nvivo, } \\
\text { MAXQDA, } \\
\text { etc. }\end{array}$ \\
\hline
\end{tabular}

Sources: compiled by authors

DRM has been slowly adopted in developing countries. The growth of internet utilization (seen from social media and e-commerce) in developing countries seems higher than in developed countries but has not been followed by the growth of social research through Internet. DRM is mostly undertaken in developing countries over ethnographic research which is less popular can be implemented beyond the area studies of anthropology and culture (Suarez, 20I8). Digital ethnography focuses on how the digital arena has become part of the material sensory and social worlds as the source of analysis. Digital ethnography harnesses digital features and has become a research strategy to grasp digital culture (Suarez, 20I8). However, by utilizing digital technology for ethnographic research, some shortcomings are also considered. Online ethnography is considerably multifaceted, multiple, and multimodal (Rybas \& Gajjala, 2007). These characteristics could be a challenge for researchers who need to produce a lot of notes to analyze virtual interactions and reflect on how these interactions reconfigure their research activities. To that point, it can be seen that digital method usage in social science research in the developing countries remain lacking and limited. If any, the use of digital method for understanding interactions may be used in ethnography research, which is used to identify interactions in social media or any other sources that appeared on the Internet. The use of supporting software to collect and analyze data is left unexplored. Besides, most literatures about DRM application and conceptualization are from the developed countries' perspectives. Thus, this article tries to fulfil the gap by exploring digital research practices from the developing countries perspectives.

\section{FINDINGS}

Positioning DRM as an alternative should be underpinned by findings and rationales that show relevance in social and humanities research activities. This part demonstrates comprehensive explanations of digital research methods and why they can be an alternative, primarily during the COVID-I9 global pandemic situation. Strengths and limitations are also shown as findings while looking up DRM to be an alternative research method in Indonesia.

\section{Digital Research Method as an Alternative}

Researchers have globally employed a contemporary approach to undertake social and humanities studies. Field study is the most popular in contemporary research implementation, which is appropriate to reveal social phenomenon, identify the pattern of social interaction, recognize language or cultural elements, and investigate cause-and-effect analysis (Ezzy, 2013). There are three instruments in contemporary approach which have been ultimately utilized for primary data collection, such as survey, in-depth interview and focus group discussion (FGD) (Weber, 20I7). However, conducting these methods generally requires a physical meeting between researchers and targeted informants to build chemistry between them, leading to a natural conver- 
sation (Kendall, 20I8). The strategy helps to identify the gesture and mimics as part of the information in the observation process.

In the meantime, the COVID-I9 global pandemic has surged since 2020 which prevents researchers to conduct research and academic activities due to safety reasons. The situation has been disrupting various research activities such as data collection, experiments, workshop, dissemination, and conferences, followed by diverse responses such as delay, reschedule, and cancellation (Myers et al., 2020). Nonetheless, the situation encourages the researcher to adapt to the restriction to travel and gather due to research activities that should be continued over uncertain conditions (when the pandemic is over). Regulating people mobility has directly constrained the data collection process, which is ultimate for social and humanities researchers, particularly human interaction as the primary source of data analysis. Digital research seems to have an opportunity to be employed as an alternative method to collect data during the pandemic since it does not require physical meeting (between researchers and research object), which is convenient to the spirit controlling COVID-I9 infection.

The development of technology innovation, such as cloud computing, artificial intelligence (AI), Big Data, mobile technologies and Internet of things (IoT) generates a bigger opportunity to explore another side phenomenon in social and humanities studies, especially social life in the digital world which may be difficult to investigate through contemporary research approach (Dutton, 2013). In other words, an advancing technology improves the flow of information and the cycle of information, which have been more rapid and access to the information. These situations potentially create a conducive environment to digitally undertake social and humanities research, particularly shaping recent issues and a new stream of research.

Concept of Digital Research Method (DRM) is a research approach that utilizes Internet and technology to obtain data, process and manipulate data, and analyze data (Bailey et al., 2015; Levenberg et al., 2018; Snee et al.,
20I6). Information technology helps researchers conduct data collection like contemporary research without face-to-face (physical) meeting. (Duca \& Metzler, 20I9; Snee et al., 2016). Through some exercises and experiments during the workshop in 2020 when the pandemic was started, we identify four elements of DRM in the context of social and humanities research, such as Digital Data, Digital software for data collection, digital software for data manipulation or data processing, and the digital software for data analysis (see Figure I). Utilizing digital data in research generally employs all DRM elements, which can be called fully digital research from retrieving data until analyzing digital demands for digital software (Howard, 2016; Jones, I999; Levenberg et al., 2018).

Figure I. Digital Research Method

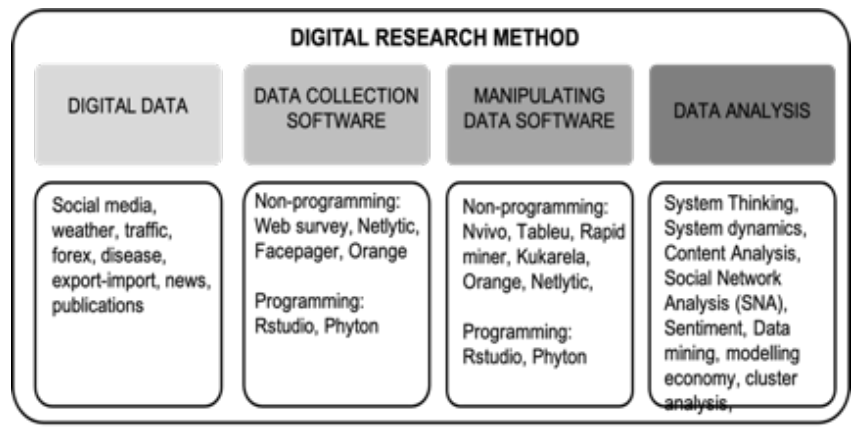

Source: Authors

In the context of the COVID-I9 global pandemic, DRM can be used to substitute a contemporary approach which is barely undertaken like in normal situation (Rifai, et al., 2020). Contrasting between the contemporary approach, DRM has several strengths that are conveniently conducted during the pandemic, particularly with almost zero contact between researchers and the research's objects leading to a low risk of infection by COVID-I9 since most of the meeting are delivered online (Figure 2). Icons in the first line represent the conventional research approach, while icons in the second line exhibit DRM. Thanks to technology, real-time communication, or conversations to gather primary data collection (for instance, in-depth interview and focus group discussion or FGD) can be done using online 
meeting platform (such as Zoom Meeting, Google Meet, Microsoft Team) or video call over online communication apps (Whatsapp, Line call, FaceTime). Based on our observation to DRM workshop's participants, we found communication apps are more appropriate to be conducted in rural areas (sub-urban) and for keypersons with limited capacity on literacy technology. The instruments seem appropriate to undertake in-depth interview since these tools are more personal instead of group communication. While video conference applications are suitable to implement formal meeting or FGD due to better quality of video and sound and ability to accommodate greater participants. Utilizing the instruments requires monthly subscriptions, sufficient bandwidth and stable internet connection, and compatibility of gadgets or computers to the software. Therefore, these instruments do not fit for all situations for data collection.

Figure 2. The Strength of DRM over Contemporary Approach in the Context of Pandemic Covid-I9

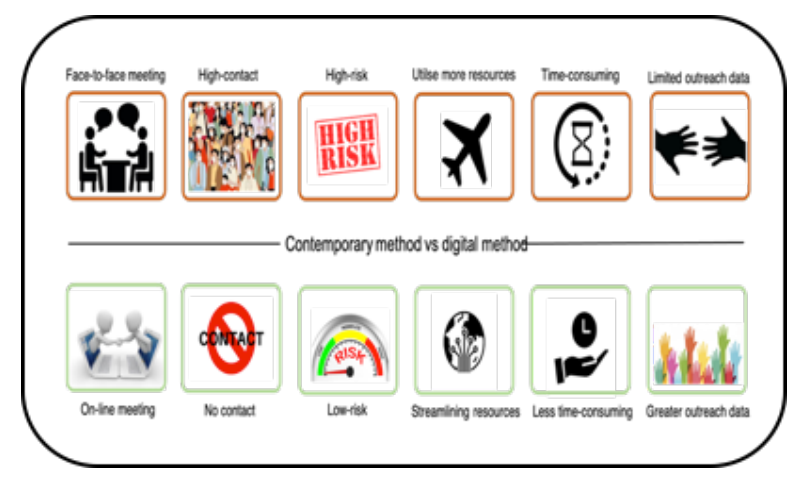

Source: Authors

While secondary data, which is dominantly in the framework of big data, can be collected using digital software that does not require physical contact. In implementing DRM in the secondary data collection, researchers should not visit the institutions or company producing the data, either printed data or digital data (by copying the files).

Furthermore, a simulation of transforming the conventional approach into DRM may be seen in the following figure. Technology development basically helps to bridge contem- porary research activities into more digitalized research activities.

Figure 3. Transformation Contemporary Approach into Digital Research Method

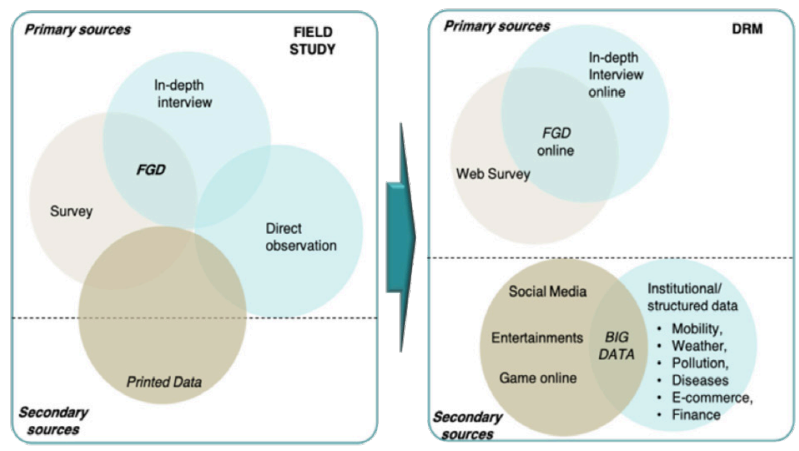

Source: (Rifai, 2020)

It can be seen from Figure 3, how technology has transformed research activities in contemporary approach into DRM. In the left side, it describes field study research, while in the right hand, it illustrates DRM activities. For instance, collecting primary data has shifted from the physical meeting into the online meeting, or direct observation has been replaced into digital observation over digital data.

However, apart from the potential advantages of DRM implementation during COVID-I9, researchers may need to aware of some crucial factors of DRM. First, to operationalize DRM, researchers should have sufficient knowledge of the concept of DRM. This helps researchers to frame digital research context relevant to data availability, appropriate research method, and ability to draw the meaning of data analysis. Second, having sufficient software skills, particularly for the software that requires computer language (such as coding or syntax). However, researchers can collaborate with a data scientist for data collection and data analysis to address this issue. Third, research should comply with digital research ethics. Data protection of research's objects must be fulfilled in regard to research ethics, for example never reveal obviously the identity of the research object and having consent from the informants before undertaking data collection. Also, data protection includes how researcher documenting and storing the 
data securely to prevent someone from utilizing the data beyond research objectives. The last, digital data only represent the situation in online life and should not be concluded as performing offline phenomenon.

Figure 4. The Crucial elements of DRM's Implementation

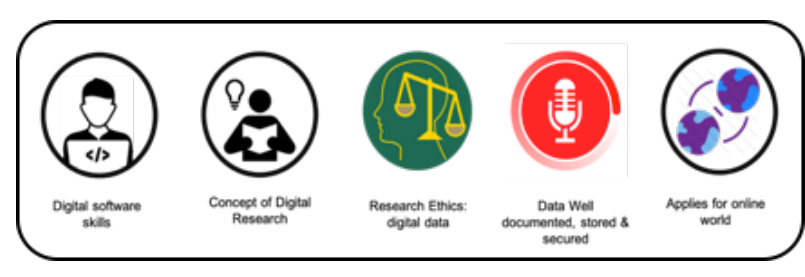

Source: Authors

\section{DIGITAL RESEARCH METHOD: STRENGTHS}

As an alternative, utilizing DRM in social and humanities research could contribute positively to the research process for data collection and data analysis. The outreach of DRM is arguably more considerable, unlimited, and timeless because of the broader arena provided and the advancement of technology that can be harnessed to gather data.

Limiting contact with the research's objects generates some advantages for scholars. Since DRM does not require scholars to travel for data collection, particularly in the COVID-I9 situation, this condition directly reduces the cost of research activities. Another benefit for minimizing travelling activities is that the DRM is more efficient in time utilization. For instance, while collecting primary data through face-to-face meetings, online interviews may replace earlier methods with technology support. Time efficiency and travel costs reduction can be seen as a positive side from shifting the earlier method by utilizing digital technology through online interviews. Hampton (20I7) also agreed that interviews conducted online could remove some costs of travel, coordination, and transcription of in-person interviews. Despite giving benefits to researchers, for some participants, interviewing online can arguably offer a safe space to address sensitive issues (Illingworth, 200I; Orgad, 2005; McCoyd \& Kerson, 2006) and include those who might find face-to-face interviews hard to fit into their lives (Madge \& O'Connor, 2002; Nicholas, et. al., 20I0). As trust established, online interactions often move offline (Session, 2010) and can inhibit the mutual interaction necessary for in-depth discussions (Hampton, 20I7). This could bring benefits for follow-up information that might be needed in the research process.

In addition, limited mobility to conduct field study or real-time observations also gives consequences to time efficiency and travel cost reduction in research activities, and for some research, online observations could replace those activities. Conducting online observations shows research strengths utilizing the digital method in which the observations that are generally conducted in real-time could now be observed in a wider range of time, including earlier time. Boelstroff (20I2) argued that although many researchers highlight the importance of observations conducted in real-time, the unique characteristic of digital technologies allows them to gather and analyze data based on a review of interactions at an earlier time (Hampton, 20I7). This can enrich the data collection, which cannot be done by a direct approach or contemporary approach in research, as mentioned earlier.

Other strengths while operationalizing DRM for primary data collection are research logistics that are normally prepared for fieldworks are minimized or even more, cancelled, and in-depth interviews, focus group discussions, and surveys which are replaced online may contribute to risk reductions and as part of health assurance to make everyone involving in the research safe. No physical contacts and social distancing procedures during the pandemic situation suggest research activities be conducted online with little logistic preparation.

Furthermore, in social and humanities research, collecting secondary data is of prominence. Utilizing DRM offers wider of the various data range, bigger outreach, and more extended historical data range (Blanke \& Prescott, 20I6; Ellingwood, 2016). The Internet may facilitate researchers to get a multifaceted and wide range of data that can be 
accessed anytime. With social media support such as Facebook and Twitter, social interactions between people can also be recorded to observe the social significance and networks established. Researchers could also determine the range of period they are desiring to gain the data. From here, various analyses could also be undertaken, for instance, social network analysis or social media analysis, to support and provide novel findings. It is also noteworthy that due to the fast circulation of information, data collection done practicing DRM is considerably faster.

\section{DIGITAL RESEARCH METHOD: LIMITATIONS}

Despite some notable strengths identified while using DRM as an alternative in social and humanities research, researchers should also be aware that digital data have some limitations, such as unstructured data and the tendency of general data derived (less specific). Thus, they require further efforts for data processing to meet the needs of the research's objectives (Blanke \& Prescott, 20i6; Brooker et al., 2016). Researchers may also need to spend another time to check the validity of digital data (Blanke \& Prescott, 2or6; Hutchinson, 2016).

Broadly, while deciding to use DRM, one of the biggest challenges is to ensure that digital infrastructures are well-maintained and have the capacity to crawl, transfer, proceed, and analyze the data. It is not uncommon that Internet access, especially in the developing countries, faces limitations, such as slow Internet connection disrupting data collection or data analysis activities. Bandwidth problems also occur, giving an impact to the slow transfer of digital data.

While using DRM, researchers could access big data that are available online. The data can be found on Facebook, Instagram, and Twitter. However, the major problem is the digital divide that remains happening in the digital world. The global digital divide describes global disparities in terms of access to computing and information resources such as the Internet and the opportunities derived from such access (Ming-Te, 200I). The digital divide may happen globally, affecting the gap in data accessibility, such as in developed and developing countries, in remote areas, outermost islands, and underdeveloped areas. The digital divide, therefore, dramatically contributes to the reluctance of DRM implementation. Better Internet connection and bandwidth will reduce terrible consequences while collecting and analyzing the data digitally.

In addition, research ethics are also concerned while conducting DRM in social and humanities research activities. Undertaking research needs to concern the rights and privacies of research subjects, especially while playing in the digital arena. Overwhelming data availability in the digital spaces sometimes leads researchers to overlook the essence of privacies, primarily when they collect the data from social media. For instance, the phenomenon of data scraping utilizing API, at some point, helps researchers to gather data, but this activity may also lead to the violation of research ethics when it is conducted illegally. In other forms of activities undertaking research digitally, such as online interviews or focus group discussions, researchers should also meet the research ethics principles, which are often neglected. Suarez informed that researchers should ask the research objects for their consents and protect their identities when conducting research (Suarez, 20I8).

In online interviews and focus group discussions, which are normally done using a qualitative approach, another limitation is that direct interactions with informants sometimes remain crucial in social and humanities research, particularly to see expressions while posing many questions. On the other hand, in a quantitative approach, DRM harnessing web-survey or online survey may also face challenges and limitations. The fact is that many people are exhausted to fill out surveys with too long questions. As a result, many questionnaire respondents only complete a half or less of the surveys. Thus, this gives a challenge for research accuracy when researchers attempt to collect data through online surveys.

Another limitation while executing DRM 
in social research is the researchers' skill set to operationalize that method. Implementing the digital method requires in-depth understanding both theoretically and practically. Researchers are also essential to grasp how to operate various software to underpin the research process and develop to some levels, digital analysis, computer, and Internet skills. Although Internet skills have been practiced since the I980s, an enormous gap between users remains occurred. This large gap creates issues ranging from students, researchers to other users (Pirzada \& Khan, 20I3). Therefore, the use of the digital method for those who are under skilled in research software and have limited experiences in utilizing Internet facilities could be more challenging and confined.

It cannot be neglected that digital skills become more extensive and are considered important to do works, including research activities. For instance, understanding the syntax and the logic of programs and tools is prominent for research harnessing DRM. Practically, researchers are necessary to learn the basic syntax, semantic, structure, and style step-by-step. Researchers must have a skill set to do all consecutive processes, encompassing designing the algorithm, translating the algorithm into program code and writing the program code with the correct syntax, at least at the basic level (Rahmat, et al., 20II). This process sounds complicated, but this is a fact that remains a challenge to be overcome for researchers if they would use DRM as an alternative method and develop it in Indonesia.

\section{CONCLUDING DISCUSSION}

In placing DRM as an alternative method, some potentials and limitations have been discussed in the preceding chapter. This part concludes and discusses crucial aspects that should be concerned while positioning DRM as an alternative method and meeting academic standards. Some pivotal aspects are as follows.

DRM application, in reality, should be highlighted by also seeing potentials and limitations that have been mentioned earlier. According to the workshops conducted, re- searchers remain unsure whether the digital tools and supporting software they use during research have been appropriate. Sometimes, the improper use of tools and software also happens, leading to potentially misleading answers for research questions. Sketchily, for instance, in applying focus group discussions and in-depth interviews, both digital and contemporary research method must grasp the functions of these data collection rituals and, if it is digitally conducted, what tools are appropriate to support the process. More widely, the developed software for data collection and data analysis are also sometimes perplexing to be used by researchers. These remain a challenge for research activities employing DRM in Indonesia.

However, by seeing the actual condition of DRM knowledge among researchers, it is noteworthy to underline that some requirements need to be fulfilled while using DRM. Digital skills and other soft skills which are necessary for appropriately using DRM in research are pivotal as a foremost requirement. Follow-up workshops that offer detailed syllabus and invite DRM experts are also needed to enhance researchers' capacities and boost confidence to use this alternative method. Affiliated institutions should also facilitate broader data access by subscribing to essential platforms or software that could support data collections and analysis. More importantly, countries in collaboration with research institutions should provide a sufficient data research environment, so researchers are more desirable to conduct digital research and maximally use digital data to contribute useful findings.

To conclude, DRM is seen potential as an alternative method amidst the uncertain pandemic situation. It is also a sign of open opportunities to develop DRM in Indonesia, which remain lagging behind. However, some aspects are still pivotal to be improved in order not only to be more advanced in science but also to guarantee the quality of knowledge itself. 


\section{REFERENCES}

Bailey, J., Mann, S., Wayal, S., Hunter, R., Free, C., Abraham, C., \& Murray, E. (2015). Digital Research Methods and Optimum Research Methodology to Evaluate Digital Interventions. In Sexual Health Promotion for Young People Delivered via Digital Media: A Scoping Review (pp. 73-83). National Institute for Health Research. https://www.ncbi.nlm.nih. gov/books/NBK326976/

Beer, D. (2013). Popular Culture and New Media: The Politics of Circulation. Palgrave Macmillan.

Blanke, T., \& Prescott, A. (20i6). Dealing with Big Data. In G. Griffin \& M. Hayler (Eds.), Research Methods for Reading Digital Data in the Digital Humanities (pp. I84-205). Edinburgh University Press.

Boellstorff, T. (2012). Ethnography and Virtual Worlds: A Handbook of Method. Princeton University Press.

Brooker, P., Barnett, J., Cribbin, T., \& Sharma, S. (20I6). Have We Even Solved the First 'Big Data Challenge?' Practical Issues Concerning Data Collection and Visual Representation for Social Media Analytics. In H. Snee, C. Hine, Y. Morey, S. Roberts, \& H. Watson (Eds.), Digital Methods for Social Science (pp. 34-50). Palgrave Macmillan.

Bruns, A \& Burgess, J. (2016). Methodological Innovation in Precarious Space: The Case of Twitter. In H. Snee, C. Hine, Y. Morey, S. Roberts, \& H. Watson (Eds.), Digital Methods For Social Science (pp. I7-33). Palgrave Macmillan.

Burgess, J. (2014) From "broadcast yourself" to "follow your interests": Making over social media. International Journal of Cultural Studies, I8 (3), 28I-285.

Burke, M., Marlow, C., Lento, T. (2010). Social network activity and social well-being. Proc. ACM CHI 2010 Conference Human Factors Computer. System, Atlanta, Georgia, pp. I909-I9I2. New York: ACM.
Camaroff, J., \& Camaroff, J. (20I2). Theory from the South: A rejoinder. The Johannesburg Salon, 30, I-II.

Duca, D., \& Metzler, K. (2019). The Ecosystem of Technologies for Social Science Research. In Sage Publishing. https://doi.org/I0.4I35/ wpigiroi

Dutton, W. H. (2013). The social shaping of digital research. International Journal of Social Research Methodology, I6(3), I77I95.

Ellison, N. B., Gray, R., Lampe, C., Fiore, A. T. (20I4). Social capital and resource requests on Facebook. New Media Social, I6, IIO4-II2I.

Ellingwood, J. (2016). An Introduction to Big Data Concepts and Terminology. Tutorial. https://www.digitalocean.com/ community/tutorials/an-introductionto-big-data-concepts-and-terminology

Evans, J. A., Aceves, P. (2016). Machine translation: mining text for social theory. Annual Review Sociology, 42, 2I-50.

Ezzy, D. (2013). Qualitative analysis. Routledge.

Fiore, A. T., Tiernan, S.L., Smith, M.A. (2002). Observed behavior and perceived value of authors in Usenet news groups: Bridging the gap. Proc. SIGCHI Conference Human Factors Computer System, Minneapolis, pp. 323-30. New York: ACM.

Freeman, L. C. (2004). The Development of Social Network Analysis: A Study in The Sociology of Science. Empirical Press Vancouver.

Gad, S., et al. (2015). ThemeDelta: dynamic segmentations over temporal topic models. IEEE Trans. Vis. Comput. Graph, 2I, 672-85. https://doi.org/ Io.IIO9/ TVCG.20I4.2388208

Haije, E. G. (202I). Top 2I Best Online Survey Software and Questionnaire Tools in 202I. https://mopinion.com/top-2Ibest-online-survey-software-andquestionnaire-tools-an-overview/ 
Hampton, K. N. (20I7). Studying the Digital: Directions and Challenges for Digital Methods. Annual Review of Sociology, 43, I67-I88.

Hampton, K.N. (2007). Neighborhoods in the network society: the e-Neighbors study. Information, Communication, Society, Io, 714-748. https://doi. org/10.1080/1369118070165806I

Hansen, D.L., Schneiderman, B., Smith, M.A. (20II). Analysing Social Media Networks with NodeXL: Insights from a Connected World. Morgan Kaufmann.

Hewson, C. (2016). Ethics Issues in Digital Methods Research. In H. Snee, C. Hine, Y. Morey, S. Roberts, \& H. Watson (Eds.), Digital Methods for Social Science (pp. 206-22I). Palgrave Macmillan.

Hine, C. (2008). Internet Research as Emergent Practice. In Hesse-Biber \& Leavy (Eds.), Handbook of Emergent Methods (pp. 52554I). The Guildford Press.

Horton, R. (2000). North and South: bridging the information gap. The Lancet, 355(9222), 223I-2236. https://doi.org/Io.IoI6/ SoI40-6736(00)024I4-4

Howard, R. G. (2016). Digital Network Analysis: Understanding Everyday Online Discourse Micro- and Macrosopically. In G. Griffin \& M. Hayler (Eds.), Research Methods for Reading Digital Data in the Digital Humanities (pp. I65-183). Edinburgh University Press.

Hutchinson, J. (20I6). An introduction to digital media research methods: how to research and the implications of new media data. Communication Research and Practice, 2(I), I-6.

Illingworth, N. (200I). The Internet matters: Exploring the use of the Internet as a research tool. Sociological Research Online 6(2), I-I2. https://doi.org/I0.5I53/sro.60o

James, N. and Busher, H. (2009) Online Interviewing. Sage Publications.

Jones, S. (1999). Doing Internet Research: Critical Issues and Methods for Examining the Net (S. Jones (ed.)). Sage Publications.
Kazmer, M.M. \& Xie. B. (2008). Qualitative interviewing in Internet studies: Playing with the media, playing with the method. Information, Communication \& Society $I I(2)$, 257-278. https://doi. org/Io.Io8o/I369II8o80i946333

Kendall, L. (20I8). The conduct of qualitative interviews. In Handbook of research on new literacies (pp. I33-I49).

Knoblauch, H. \& Schnettler, B. (20I2) Videography: Analysing video data as a "focused" ethnographic and hermeneutical exercise. Qualitative Research, I2(3), 334-56.

Koehn, P. H. (20I4). Developments in Transnational Research Collaborations: Evidence from U.S. Higher-education Activity. Journal of New Approaches in Educational Research, 3(2), 52-58. https:// doi.org/I0.782I/naer.3.2.52-58

Krippendorff, K. (2004). Content Analysis, an Introduction to Its Methodology. Sage.

Lazer, D., Pentland, P., Adamic, L., Aral, S., Barabasi, A., Brewer, D., \& Chistakis, N. (2009). Computational Social Science. Science 323, 72I-723. https://doi.org/ IO.II26/science.II67742

Levenberg, L., Neilson, T., \& Rheams, D. (2018). Research Methods in the Digital Humanities. In Routledge International Handbook of Research Methods in Digital Humanities. Palgrave Macmillan. https:// doi.org/I0.4324/9780429777028-I

Madge, C. and O'Connor, H. (2002) Online with the e-mums: Exploring the Internet as a medium for research. Area, 34, 92IO2.

McCoyd, J.L.M. \& Kerson, T.S. (2006) Conducting intensive interviews using email. Qualitative Social Work, 5(3), 389406.

Ming-Te. (200I). Digital Divide in Developing Countries. Journal of Global Information Technology Management, 4(3), I-4. https://doi.org/Io.Io 8 o/I 097 I 9 8X.200I.10856304. 
Morstatter, F., Pfeffer, J., Liu, H., \& Carley, K. M. (2013). Is the sample good enough? Comparing data from Twitter's streaming API with Twitter's Firehose. Proc. 7 th Int. AAAI Conf. Weblogs Soc. Media, Cambridge, July 8-II, pp. 4004088. AAAI Press.

Myers, K., Tham, W. Y., Yin, Y., Cohodes, N., Thursby, J. G., Thursby, M., \& Wang, D. (2020). Quantifying the immediate effects of the COVID-I9 pandemic on scientists. SSRN, 3608302, I-39.

Nicholas, D.B., Lach, L., King, G., Scott, M., Boydell, K., Sawatzky, B.J., Resiman, J., Schippel, E. \& Young, N.L. (20I0) Contrasting Internet and face-to- face focus groups for children with chronic health conditions: Outcomes and participant experiences. International Journal of Qualitative Methods, 9(I), I05$2 \mathrm{I}$.

Orgad, S.S. (2005) Storytelling Online: Talking Breast Cancer on the Internet. Peter Lang.

Pirzada, K. \& Khan, F. (2013). Measuring Relationship between Digital Skills and Employability. European Journal of Business and Management, 5(24), I24-I34.

Rahmat, M., Shahrani, S., Latih, R., \& Yatim, N. F. M. (20II). Major problems in basic programming that influence student performance. Procedia - Social and Behavioral Sciences, 59 (2012), 287-296. https://doi.org/ Io.IoI6/j. sbspro.2012.09.277

Rifai, B. (2020). Produktif Meneliti Melalui Metode Riset Digital.

Rifai, B., Barid, V. B., Kurniawan, F. E., \& Yayusman, M. S. (2020). Model Transformasi Riset Digital Sebagai Alternatif Metode Penelitian Sosial Humaniora.

Rogers, R. (2015). Digital Methods for Web Research. Emerging Trends in the Social and Behavioral Sciences. I-22. https://doi. org/Io.I002/978III8900772.etrdsoo76
Roock, R., Bhatt, I., \& Adams, J. (20I6). Video Analysis in Digital Literacy Studies: Exploring Innovative Methods. In $\mathrm{H}$. Snee, C. Hine, Y. Morey, S. Roberts, \& H. Watson (Eds.), Digital Methods For Social Science (pp. I05-I2I). Palgrave Macmillan.

Rybas, N., \& Gajjala, R. (2007). Developing Cyberethnographic Research Methods for Understanding Digitally Mediated Identities. Forum Qualitative Sozialforschung / Forum: Qualitative Social Research.

Salmons, J. (2009) Online Interviews in Real Time. Sage Publications.

Sandvig, C. \& Hargittai, E. (2015). How to Think about Digital Research. In E. Hargittai \& C. Sandvig (Eds.), Digital Research Confidential The Secret of Studying Behavior Online (pp. I-28). The MITT Press.

Schober, M. F., Pasek, J., Guggenheim, L., Lampe, C., Conrad, F.G. (2016). Social media analyses for social measurement. Public Opinion Quarterly, 80, I80-2II.

Sessions, L, F. (2010). How offline gatherings affect online communities: when virtual community members "meetup." Information, Communication, Society, I3, 375-395.

Shapka, J.D., Domene, J. F., Khan, S., \& Yang, L. M. (2016). Online versus inperson interviews with adoloscents: An explorations of data equivalence. Computers in Human Behavior, 58, 36I367.

Shumate, M. \& Weber, M. (2015). The Art of Web Crawling for Social Science Research. In E. Hargittai \& C. Sandvig (Eds.), Digital Research Confidential The Secret of Studying Behavior Online (pp. 20I-222). The MITT Press.

Snee, H., Hine, C., Morey, Y., Roberts, S., \& Watson, H. (20I6). Digital Methods as Mainstream Methodology: An Introduction. In H. Snee, C. Hine, Y. Morey, S. Roberts, \& H. Watson (Eds.), Digital Methods For Social Science (pp. I-II). Palgrave Macmillan. 
Suarez, M. (20I8). What can multi-sited and digital ethnography contribute to innovation studies in the global South?. African Journal of Science, Technology, Innovation and development. https://doi. org/10.1080/20421338.2018.1528703

Turner, T. C., Smith, M. A., Fisher, D., \& Welse, H. (2005). Picturing Usenet: Mapping computer-mediated collective action. Journal of Computer Mediated Communication IO (4), 7. https://doi. org/ro.IIII/j.I083-6Ior.2005.tboo270.x

Weber, M. (20I7). Methodology of social sciences.

Welles, B. F. (2015). Big Data, Big Problems, Big Opportunities: Using Internet Log Data to Conduct Social Network Analysis. In E. Hargittai \& C. Sandvig (Eds.), Digital Research Confidential The Secret of Studying Behavior Online (pp.223-242). The MITT Press.

Wesler H, Smith M, Fisher D \& Gleave E. (2008). Distilling digital traces: computational social science approaches to studying the Internet. In N. Fielding, R.M. Lee, \& G. Blank (Eds.), The Sage Handbook of Online Research Methods (pp. II6-I40). SAGE.

Wetherell, C., Plakans, A., \& Wellman, B. (I994). Social Networks, Kinship, and Community in Eastern Europe. Journal of Interdisciplinary History, 24 (I), 639-663.

Wildemuth, B. M. (2016). Applications of social research methods to questions in information and library science. In B. M. Wildemuth (Ed.), Applications of social research methods to questions in information and library science (2nd ed.). Libraries Unlimited.

Zhang, M. (20I0). Social Network Analysis: History, Concept, and Research. In B. Furht (Ed.), Handbook of Social Network Technologies and Applications (pp. 3-2I). Springer.

\section{AUTHOR BIOGRAPHIES}

Dr. Bahtiar Rifai is an economic researcher for the Indonesian Institute of Sciences (LIPI). Graduated from the University of Birmingham, the United Kingdom, he focuses his study on knowledge production, knowledgebased economy, technology, and innovation economics. Bahtiar has been awarded by Australian Awards Scholarship (AAS) for Digital Age fellowship at Griffith University, Australia. His research in Indonesia investigates digital government, digital technology adoption in the manufacturing sector, and promoting digital research methods for social sciences and humanities.

Meilinda Sari Yayusman is a researcher at Research Center for Area Studies, the Indonesian Institute of Sciences (LIPI). She has graduated from the University of Groningen majoring in International Relations-European Integration. Her research interests encompass international relations in Europe, human rights, and digital human rights.

Vera Bararah Barid is a junior researcher at Research Center for Population, the Indonesian Institute of Sciences (LIPI). She has graduated from the University of Indonesia, Faculty of Law majoring in Criminal Justice System. Her research interests about labor of law such as: social protection, legal protection for workers, wages, etc.. 